\title{
Diachronic changes in linear enamel hypoplasia during the Edo period (1603-1867), Japan
}

\author{
Nana NAKAYAMA ${ }^{1 *}$ \\ ${ }^{1}$ Advanced Research Center for Human Sciences, Waseda University, 2-579-15, Mikajima, Tokorozawa, Saitama 359-1192, Japan
}

Received 11 August 2018; accepted 3 March 2019

\begin{abstract}
Linear enamel hypoplasia (LEH) is a useful indicator of childhood health. This study aimed at investigating whether there was any diachronic change in LEH occurrence during the Edo period (1603-1867). The Edo period, which experienced no major transition in subsistence and had no largescale contact with foreign population, did undergo various social changes that could have affected childhood health status. The skeletal remains of 144 adult individuals recovered from seven burial sites in Tokyo were examined. Based on historical records and archaeological evidence, these individuals were divided into two time-period groups, the early Edo period and the late Edo period. Each group was then subdivided into the two age-at-death groups of young and old. The late Edo period groups were also divided into coffin-type groups, which reflect their social status. Comparison of general prevalence, frequency distribution, and the mean number of LEHs observed per tooth revealed that the individuals of the late Edo period groups of any coffin type tend to have fewer LEHs than those of the early Edo period groups, and significant differences were found either in the frequency distribution or in the mean number of LEHs per tooth. Considering the possible factors that could affect the result, such as age-atdeath distribution and social status, the observed difference between the time periods can be attributed to diachronic change, which is assumed to be due to improvements in childhood health status during the Edo period. This assumption is compatible with historical evidence suggesting that the living environment in the city of Edo was improving in the 17th century and stabilized in the 18th century as a result of the establishment of basic infrastructure and improvements in public safety. The findings of this study will help us understand childhood health status in a changing society.
\end{abstract}

Key words: enamel hypoplasia, stress indicator, Edo

\section{Introduction}

Enamel hypoplasia is a developmental defect of dental enamel characterized by a deficiency in the thickness of the enamel. It is expressed in the form of pits, linear grooves, or planes on the enamel surface, among which the linear grooves or linear enamel hypoplasia (LEH) are the most common (Hillson, 1996). Various environmental factors, as well as genetic factors, are thought to be the cause of disturbances of the enamel formation process (Seow, 2014), and associations between enamel hypoplasia and low birthweight (Aine et al., 2000), malnutrition (May et al., 1993; Zhou and Corruccini, 1998), infections (Seow, 2014), and other systemic diseases have been demonstrated by clinical and epidemiological studies. Furthermore, once the hypoplasia forms, it remains on the enamel surface for the entire-

\footnotetext{
* Correspondence to: Nana Nakayama, Advanced Research Center for Human Sciences, Waseda University, 2-579-15, Mikajima, Tokorozawa, Saitama 359-1192, Japan.

E-mail: 7-nana@ruri.waseda.jp

Published online 9 April 2019

in J-STAGE (www.jstage.jst.go.jp) DOI: 10.1537/ase.190303
}

ty of an individual's lifetime unless it is worn away. Although it is almost impossible to determine the exact cause of LEH observed on skeletal samples, LEH is still a useful indicator of systemic stress and health status during childhood in past populations and has been used in numerous bioarchaeological studies (Goodman and Rose, 1990; King et al., 2005).

One of the main topics of bioarchaeological studies of enamel hypoplasia is diachronic change in the hypoplasia occurrence pattern. Typically, diachronic changes in the hypoplasia occurrence pattern have been associated with social changes, especially transitions in subsistence. Cucina (2002), for example, demonstrated that the frequency of hypoplasia among populations from Trentino, Italy, increased as this society shifted from the Neolithic to the Copper Age and into the Early Bronze Age. This study also suggested that changes in nutrition and cultural habits, accompanied by a transition from foraging to agriculture and agropastoralism, might underlie these changes in hypoplasia frequency (Cucina, 2002). Similarly, Lanphear (1990) showed that the lowest social class in the 19th-century American population also suffered from higher levels of childhood stress than populations of preceding time periods, and associated this 
result with the shift from an agricultural to industrial society. However, Griffin and Donlon (2007) concluded that the transition between the Middle Bronze Age and Early Iron Age in Jordan was not sufficiently stressful to cause a dramatic deterioration in the health of the population.

Full-scale contacts with foreign populations have also been shown to have tremendous impacts on childhood health status. For example, a significant increase in hypoplasia was observed among Aboriginal Australians after their contact with Europeans intensified (Littleton, 2005), while a similar increase was seen among the Tupi-Monde Amerindians in the Brazilian Amazon after they began to have permanent contact with Brazilian society at large (Santos and Coimbra, 1999).

However, it remains an open question whether any diachronic change in the hypoplasia occurrence pattern can be observed in populations that have experienced no major transition in subsistence or full-scale contact with foreign populations. The Japanese population of the Edo period (1603-1867) is ideal to examine diachronic changes in the hypoplasia occurrence pattern, as throughout the Edo period, Japanese society was primarily agricultural and ruled by the Tokugawa Shogunate, which strictly controlled contact between the Japanese and foreign populations. At the same time, Japanese society experienced significant social changes, including a marked increase in population (Kito, 2001) and the foundation of several large cities (Naito, 1966), which could have affected the childhood health status. Further, the Edo period is ideal for this study as the burial dates can be estimated from written records of graveyards, allowing for the examination of any diachronic changes in the relatively short time period.

Yamamoto (1988) and Koga (2003) previously investigated diachronic changes in hypoplasia throughout Japanese history, from the prehistoric Jomon period to the modern period. They revealed that the transition from huntergathering to agriculture accompanied the reduction in hypoplasia prevalence, while the development of large cities in the Edo period resulted in the increased prevalence of hypoplasia (Yamamoto, 1988; Koga, 2003). However, whether there was any diachronic change in the occurrence of hypoplasia during the Edo period remains unexamined.

The present study aims at investigating diachronic changes in LEH occurrence patterns and general childhood health status during the Edo period. Specifically, this study compares the LEH occurrence pattern among the early Edo period population (i.e. the 17 th century) and that among the late Edo period population (i.e. the 18th and 19th centuries).

\section{Materials and Methods}

Adult skeletal remains recovered from seven burial sites in Tokyo, Japan (Figure 1, Table 1) were examined for this study. All of these sites were temple graveyards from within the city range of Edo dating to the Edo period. All skeletal remains are housed in the Department of Anthropology of the National Museum of Nature and Science in Tsukuba.

The burial sites differ regarding the time period that the graveyards were in use. According to the old maps and written records of the temple and the Tokugawa Shogunate, the Hatchobori-Sanchome site was occupied by a graveyard from the end of the 16th century to the mid-17th century

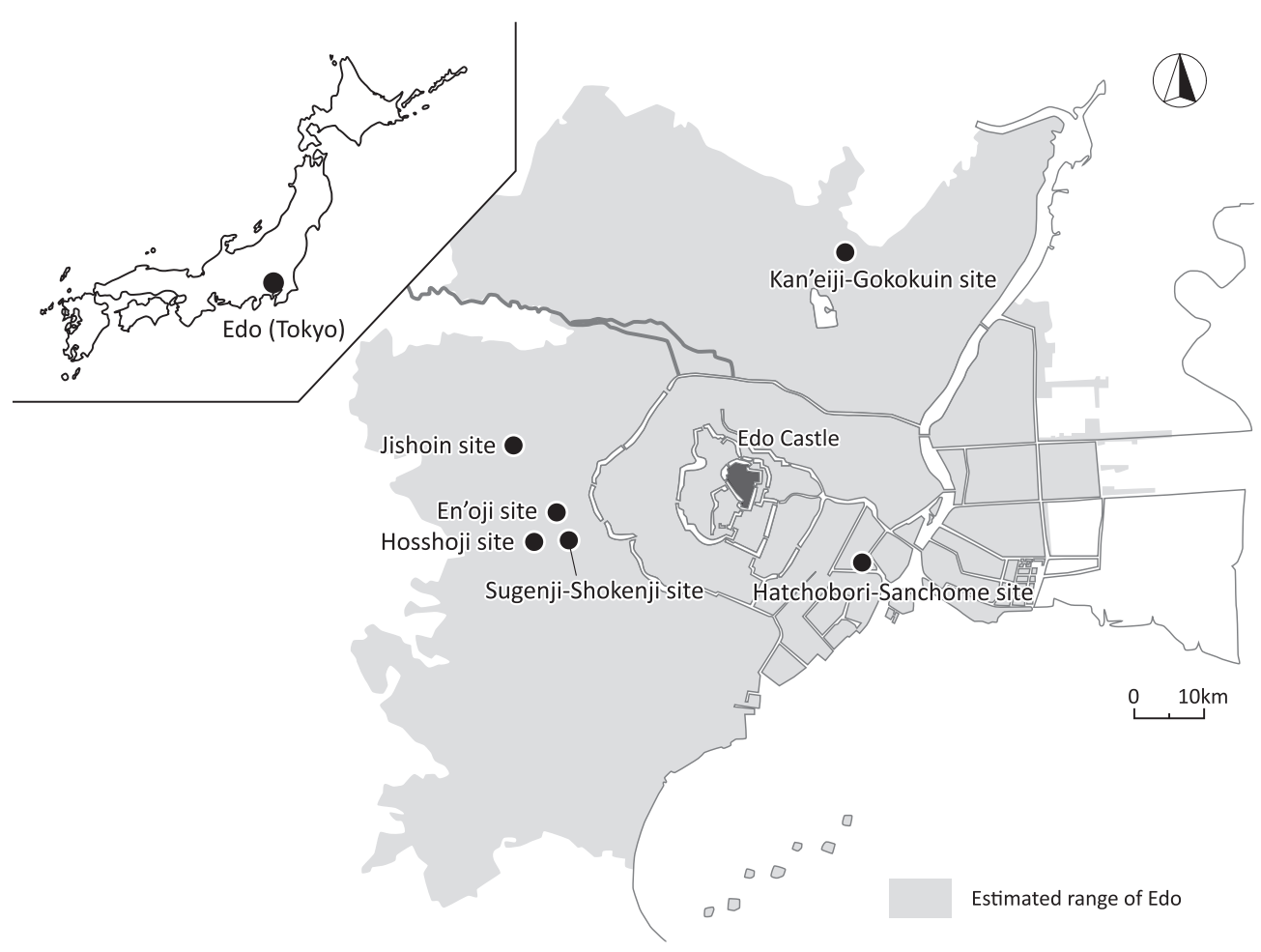

Figure 1. Locations of the burial sites examined in this study. 
Table 1. Burial sites examined in this study

\begin{tabular}{|c|c|c|c|}
\hline Site & $\begin{array}{c}\text { Time period of } \\
\text { excavated burials }\end{array}$ & $\begin{array}{c}\text { Number of } \\
\text { individuals examined }\end{array}$ & References \\
\hline $\begin{array}{l}\text { Hatchobori } \\
\text { Sanchome }\end{array}$ & $\begin{array}{l}\text { End of } 16 \text { th century } \\
\text { to the mid-17th century }\end{array}$ & 29 & $\begin{array}{l}\text { Tokyoto Chuoku Kyouiku Iinkai, } 1988 \\
\text { Tokyoto Chuoku Kyouiku Iinkai, } 1989 \\
\text { Hatchobori Sanchome Iseki Dainiji Chousakai, } 2003\end{array}$ \\
\hline Sugenji & $\begin{array}{l}\text { Late } 17 \text { th century } \\
\text { to late } 19 \text { th century }\end{array}$ & 55 & Taisei Enjiniaringu Kabushiki Gaisha, 2005 \\
\hline Shokenji & $\begin{array}{l}\text { Late } 17 \text { th century } \\
\quad \text { to late } 19 \text { th century }\end{array}$ & 27 & Taisei Enjiniaringu Kabushiki Gaisha, 2005 \\
\hline Hosshoji & $\begin{array}{l}\text { Late } 17 \text { th century } \\
\quad \text { to late } 19 \text { th century }\end{array}$ & 14 & Shinjukuku Hosshojiato Iseki Chosakai, 1991 \\
\hline En'oji & $\begin{array}{l}\text { Early } 18 \text { th century } \\
\quad \text { to late } 19 \text { th century }\end{array}$ & 9 & Shinjukuku Koseibu Iseki Chosakai, 1993 \\
\hline $\begin{array}{l}\text { Kan'eiji } \\
\text { Gokokuin }\end{array}$ & $\begin{array}{l}\text { Early } 18 \text { th century } \\
\quad \text { to late } 19 \text { th century }\end{array}$ & 7 & Toritsugakko Iseki Chosakai, 1990 \\
\hline Jishoin & $\begin{array}{l}\text { Late } 17 \text { th century } \\
\text { to late } 19 \text { th century }\end{array}$ & 3 & Jishoin Iseki Chosadan, 1987 \\
\hline
\end{tabular}

(Table 1). In the other sites, documentary records and archaeological evidence, such as burial position, the typological traits of coffins, and burial goods, indicate that the majority of burials dated to the 18th and 19th centuries, although some date back to the late 17 th century (Table 1). In this study, the individuals recovered from the HatchoboriSanchome site were categorized as the early Edo period group, and individuals from the other sites were categorized as the late Edo period group. Individuals from the late Edo period sites that date to the 17 th century were excluded from the study.

The individuals observed in this study also differ in social status. An absolute hierarchy of social status was characteristic of the Edo period society, which was established by the beginning of the 18 th century (Asao, 1992). It is necessary to consider social status to make an effective comparison between the groups of different time periods, as a previous study revealed that higher-status individuals had fewer LEHs than lower-status individuals in 18th- and 19thcentury Edo (Nakayama, 2016). In the late Edo period, coffin types were closely associated with the social status of the deceased (Matsumoto, 1990; Tanigawa, 1992, 1993, 2004). Based on this association, the late Edo period individuals were subdivided into three different coffin-type groups: jar coffins or the kamekan group (middle-class warriors), square coffins or the houkeimokkan group (low-class warriors and townspeople including merchants and craftspeople), and circular coffins or the enkeimokkan group (townspeople). Because the hierarchy of social status was not fully established in the early 17 th century, the social status of early Edo period individuals, unlike the late Edo period individuals, cannot be estimated from their burial coffin type. If any type of economic or environmental inequality existed during the early Edo period, no associations between burials and economic or environmental conditions have been identified. Therefore, in this study, the early Edo period group was compared with the pooled late Edo period group and with each coffin type group to look for any systematic differences in LEH occurrence patterns between the two time periods.

Burials that contained more than one individual were excluded from the study, as any additional interments or distur- bances would obscure the date of the initial burial.

Age-at-death and sex were also considered in this study. Several earlier studies showed that LEH is related to age at death, and those who died in their early adulthood tend to have more LEH than those who survived into their late adulthood (Šlaus, 2000; Palubeckaitè et al., 2002). Koga (2003) also pointed out that younger adults showed higher prevalence of hypoplasia than older adults in his study on the prehistoric and historic populations of western Japan. These studies indicate that differences in the proportion of young adults to old adults in a skeletal population can lead to variation in LEH prevalence even if childhood health status is unchanged. As for the sex difference, significant differences in LEH prevalence were found in the Edo period population in Fukuoka, western Japan (Oyamada et al., 2012).

The age at death of an individual was estimated using the system described by Lovejoy et al. (1985). The individuals were then divided into two age-at-death groups: young and old. The young age corresponds to phase 1 and 2 of Lovejoy et al. (1985), which are represented by the presence of distinctive billowing and fine granularity on the auricular surface. The old age corresponds to phases 3-8, which are represented by the loss of billowing and coarser granularity. Sex determination was based on os coxae observations following Bruzek (2002). A total of 144 individuals were examined for this study.

Right mandibular canines were selected for the observation of LEH, because hypoplasias are identified more frequently on anterior teeth than on molars due to the difference in tooth crown geometry (Hillson and Bond, 1997; King et al., 2002). Furthermore, mandibular canines were better preserved than other anterior teeth in the individuals of this study. When the right one was missing, the left mandibular canine was used. The tooth surface was observed macroscopically using an LED light (Gentos LU-185), and the presence of a defect was confirmed by palpating the surface with a wooden toothpick. Teeth whose labial surface was covered with calculus were excluded from this study.

The degree of occlusal attrition and buccal attrition were also considered in this study to examine the effect of occlusal and buccal attrition on the number of LEHs per tooth. 
The occlusal attrition was recorded using Molnar's (1971) system. Teeth evaluated as $\leq 2$ were categorized as 'mild' and those evaluated as 3 were categorized as 'severe.' Teeth evaluated as $\geq 4$ were excluded from the study. As for the buccal attrition, Edo period individuals often had polished teeth caused by customary brushing (Oyamada et al., 2004). In this study, teeth whose perikymata on buccal surface were visible to the naked eye were recorded as 'mild,' and teeth whose perikymata were invisible to the naked eye were recorded as 'severe.' Teeth whose dentins were exposed on the buccal surface were excluded from the study. These excluded teeth correspond to the 'hard polished teeth' and teeth with 'wedge-shaped defects' reported by Oyamada et al. (2004).

The frequency distribution of the number of LEHs per tooth and the average number of LEHs per tooth were calculated according to sex, age at death, time period, coffin type, and degree of attrition.

Fisher's exact test was performed to assess the significance of difference in the age-at-death proportion, general prevalence of LEHs, and the frequency distribution of the number of LEHs per tooth between each group. Significance of difference in the average number of LEHs was assessed by $t$-test. These statistical tests were performed using R 3.1.1 software (R Core Team, 2014), with a significance level of 0.05 .

\section{Results}

\section{Age at death and sex distribution}

Table 2 shows the number and proportion of individuals in each age-at-death and sex group. The age at death varied according to the time period; the early Edo period group included a higher proportion of young individuals compared to the pooled late Edo period group, and to each coffin-type group. As for the sex distribution, there were more male individuals in the early Edo period group, in the pooled late Edo period group, and in the circular coffin group. The proportion of male individuals in the jar coffin group was almost equal to that of female individuals, and the square coffin group had a lower proportion of males than females.

\section{General prevalence and number of LEHs per tooth}

The general prevalence of LEH and the number of LEHs observed on each tooth is shown in Table 3 according to the time period, coffin types, age at death, and sex. Figure 2 shows the percentage frequency distribution of the number of LEHs per tooth by age at death, time periods, and coffin types. Overall, the general prevalence of LEH was very high, exceeding $80 \%$, regardless of the age at death, time period, or coffin types.

\section{Difference between sexes}

Comparison of the general prevalence, frequency distribution, and the mean number of LEHs per tooth between sexes revealed no significant difference in any age-at-death group of any time period or coffin group ( $P \geq 0.05$; Table 4$)$. Therefore, sexes were pooled in the following comparison.

\section{Difference between age-at-death groups}

The results of a significance test between the young and old groups are summarized in Table 5. There was no significant difference in the general prevalence of $\mathrm{LEH}$ between the young and old individuals in any time period or in any coffin group $(P \geq 0.05)$. However, significant differences between the young and old individuals were found in the frequency distribution of LEH in the early Edo period group and in the pooled late Edo period group $(P<0.05)$, although no significant difference was found between the two age-atdeath groups of the jar coffin group or of the circular coffin group $(P \geq 0.05)$. In addition, young individuals frequently surpassed old individuals in the mean number of LEHs per tooth, and a significant difference in the mean number of LEHs was found between the two age-at-death groups in the pooled late Edo period group $(P<0.05)$. No significant difference was found in the mean number of LEHs between the two age-at-death groups of the early Edo period group, the jar coffin group, or the circular coffin group $(P \geq 0.05)$.

\section{Difference between time periods}

The frequency distributions of LEH of the late Edo period groups had a tendency to concentrate on a smaller number than those of the early Edo period groups (Figure 2). The late Edo period groups also tended to have lower mean number of LEHs per tooth than the early Edo period groups. When the age-at-death categories were pooled, the frequency distribution in the early Edo period group was significantly different from that in the pooled late Edo period group and that in each coffin group $(P<0.05$; Table 6$)$. The pooled late Edo period group and the jar coffin also had significantly lower mean numbers of LEHs per tooth than the early Edo period group $(P<0.05$; Table 6$)$. Comparisons between the young groups revealed that the frequency distributions of the pooled late Edo period group and of the circular coffin group

Table 2. Number of individuals examined in this study

\begin{tabular}{|c|c|c|c|c|c|}
\hline & \multicolumn{2}{|c|}{ Young } & \multicolumn{2}{|c|}{ Old } & \multirow{2}{*}{ Total } \\
\hline & Male & Female & Male & Female & \\
\hline Early Edo period & $6(20.7 \%)$ & $4(13.8 \%)$ & $13(44.8 \%)$ & $6(20.7 \%)$ & $29(100.0 \%)$ \\
\hline \multicolumn{6}{|l|}{ Late Edo period } \\
\hline Pooled coffin & $9 \quad(7.8 \%)$ & $10 \quad(8.7 \%)$ & $61(53.0 \%)$ & $35(30.4 \%)$ & $115(100.0 \%)$ \\
\hline Jar coffin & $3(6.1 \%)$ & $8(16.3 \%)$ & $21(42.9 \%)$ & $17(34.7 \%)$ & $49(100.0 \%)$ \\
\hline Wooden square coffin & $0 \quad(0.0 \%)$ & $0 \quad(0.0 \%)$ & $6(37.5 \%)$ & $10(62.5 \%)$ & $16(100.0 \%)$ \\
\hline Wooden circular coffin & $6(12.0 \%)$ & $2(4.0 \%)$ & $34(68.0 \%)$ & $8(16.0 \%)$ & $50(100.0 \%)$ \\
\hline
\end{tabular}

The percentages in parentheses indicate the percentages of individuals in each time-period and coffin-type group. 
Table 3. General prevalence of LEH and number of LEHs per tooth

\begin{tabular}{|c|c|c|c|c|c|c|c|c|c|}
\hline & \multirow{2}{*}{$\begin{array}{c}\text { General } \\
\text { prevalence }(\%)\end{array}$} & \multicolumn{7}{|c|}{ Number of LEHs per tooth } & \multirow{2}{*}{$\begin{array}{l}\text { Mean number o } \\
\text { LEHs per tooth }\end{array}$} \\
\hline & & 0 & 1 & 2 & 3 & 4 & 5 & 6 & \\
\hline \multicolumn{10}{|c|}{ Early Edo period } \\
\hline \multicolumn{10}{|c|}{ Young } \\
\hline Male & 83.3 & 1 & 0 & 1 & 0 & 1 & 3 & 0 & 3.5 \\
\hline Female & 100.0 & 0 & 0 & 0 & 1 & 1 & 2 & 0 & 4.3 \\
\hline Total & 90.0 & 1 & 0 & 1 & 1 & 2 & 5 & 0 & 3.8 \\
\hline \multicolumn{10}{|l|}{ Old } \\
\hline Male & 100.0 & 0 & 0 & 4 & 3 & 5 & 1 & 0 & 3.2 \\
\hline Female & 100.0 & 0 & 0 & 1 & 2 & 3 & 0 & 0 & 3.3 \\
\hline Total & 100.0 & 0 & 0 & 5 & 5 & 8 & 1 & 0 & 3.3 \\
\hline \multicolumn{10}{|c|}{ Pooled age at death } \\
\hline Male & 94.7 & 1 & 0 & 5 & 3 & 6 & 4 & 0 & 3.3 \\
\hline Female & 100.0 & 0 & 0 & 1 & 3 & 4 & 2 & 0 & 3.7 \\
\hline Total & 96.6 & 1 & 0 & 6 & 6 & 10 & 6 & 0 & 3.4 \\
\hline \multicolumn{10}{|l|}{ Late Edo period } \\
\hline \multicolumn{10}{|c|}{ Pooled coffin types } \\
\hline \multicolumn{10}{|c|}{ Young } \\
\hline Male & 100.0 & 0 & 0 & 2 & 5 & 1 & 0 & 1 & 3.2 \\
\hline Female & 100.0 & 0 & 1 & 3 & 4 & 0 & 2 & 0 & 2.9 \\
\hline Total & 100.0 & 0 & 1 & 5 & 9 & 1 & 2 & 1 & 3.1 \\
\hline \multicolumn{10}{|l|}{ Old } \\
\hline Male & 93.4 & 4 & 8 & 13 & 24 & 11 & 1 & 0 & 2.5 \\
\hline Female & 91.4 & 3 & 4 & 15 & 8 & 5 & 0 & 0 & 2.2 \\
\hline Total & 92.7 & 7 & 12 & 28 & 32 & 16 & 1 & 0 & 2.4 \\
\hline \multicolumn{10}{|c|}{ Pooled age at death } \\
\hline Male & 94.3 & 4 & 8 & 15 & 29 & 12 & 1 & 1 & 2.6 \\
\hline Female & 93.3 & 3 & 5 & 18 & 12 & 5 & 2 & 0 & 2.4 \\
\hline Total & 93.9 & 7 & 13 & 33 & 41 & 17 & 3 & 1 & 2.5 \\
\hline \multicolumn{10}{|l|}{ Jar coffin } \\
\hline \multicolumn{10}{|l|}{ Young } \\
\hline Male & 100.0 & 0 & 0 & 1 & 1 & 1 & 0 & 0 & 3.0 \\
\hline Female & 100.0 & 0 & 1 & 3 & 3 & 0 & 1 & 0 & 2.6 \\
\hline Total & 100.0 & 0 & 1 & 4 & 4 & 1 & 1 & 0 & 2.7 \\
\hline Old & & & & & & & & & \\
\hline Male & 81.0 & 4 & 3 & 6 & 7 & 1 & 0 & 0 & 1.9 \\
\hline Female & 88.2 & 2 & 1 & 9 & 2 & 3 & 0 & 0 & 2.2 \\
\hline Total & 84.2 & 6 & 4 & 15 & 9 & 4 & 0 & 0 & 2.0 \\
\hline Pooled age & & & & & & & & & \\
\hline Male & 83.3 & 4 & 3 & 7 & 8 & 2 & 0 & 0 & 2.0 \\
\hline Female & 92.0 & 2 & 2 & 12 & 5 & 3 & 1 & 0 & 2.3 \\
\hline Total & 87.8 & 6 & 5 & 19 & 13 & 5 & 1 & 0 & 2.2 \\
\hline Wooden squ & & & & & & & & & \\
\hline Old & & & & & & & & & \\
\hline Male & 100.0 & 0 & 3 & 0 & 2 & 1 & 0 & 0 & 2.2 \\
\hline Female & 100.0 & 0 & 2 & 4 & 3 & 1 & 0 & 0 & 2.3 \\
\hline Total & 100.0 & 0 & 5 & 4 & 5 & 2 & 0 & 0 & 2.3 \\
\hline Wooden circ & & & & & & & & & \\
\hline Young & & & & & & & & & \\
\hline Male & 100.0 & 0 & 0 & 1 & 4 & 0 & 0 & 1 & 3.3 \\
\hline Female & 100.0 & 0 & 0 & 0 & 1 & 0 & 1 & 0 & 4.0 \\
\hline Total & 100.0 & 0 & 0 & 1 & 5 & 0 & 1 & 1 & 3.5 \\
\hline Old & & & & & & & & & \\
\hline Male & 100.0 & 0 & 2 & 7 & 15 & 9 & 1 & 0 & 3.0 \\
\hline Female & 87.5 & 1 & 1 & 2 & 3 & 1 & 0 & 0 & 2.3 \\
\hline Total & 97.6 & 1 & 3 & 9 & 18 & 10 & 1 & 0 & 2.9 \\
\hline Pooled age & & & & & & & & & \\
\hline Male & 100.0 & 0 & 2 & 8 & 19 & 9 & 1 & 1 & 3.1 \\
\hline Female & 90.0 & 1 & 1 & 2 & 4 & 1 & 1 & 0 & 2.6 \\
\hline Total & 98.0 & 1 & 3 & 10 & 23 & 10 & 2 & 1 & 3.0 \\
\hline
\end{tabular}




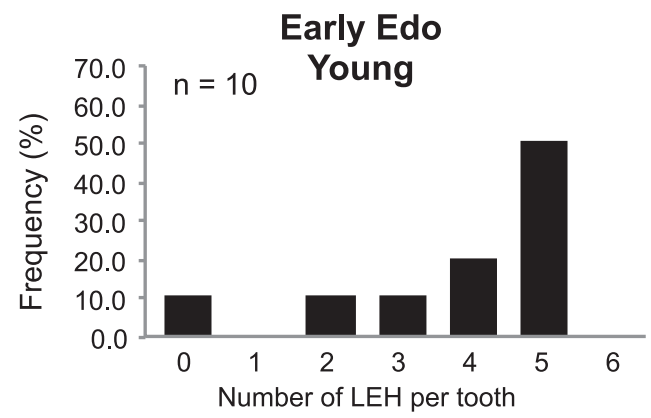

Late Edo, pooled coffin types

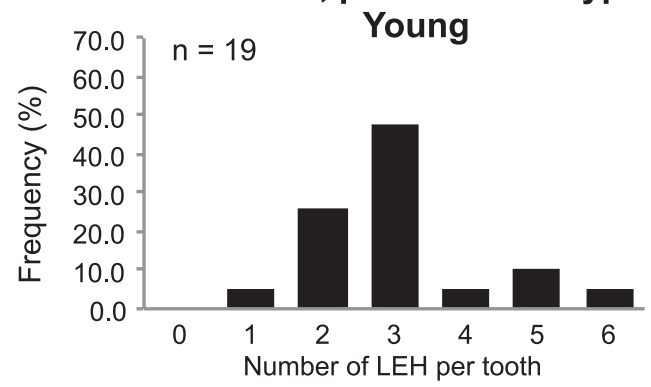

Late Edo, jar coffin

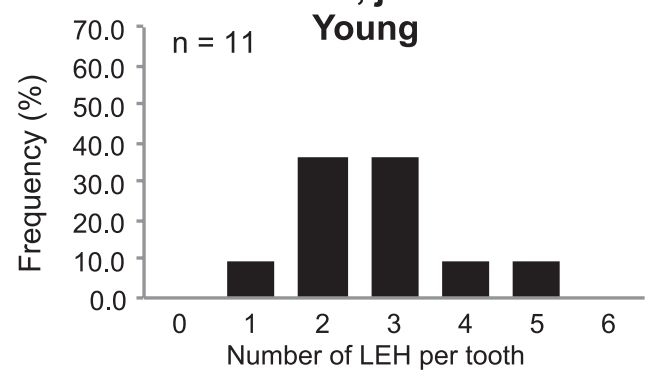

Late Edo, circular coffin

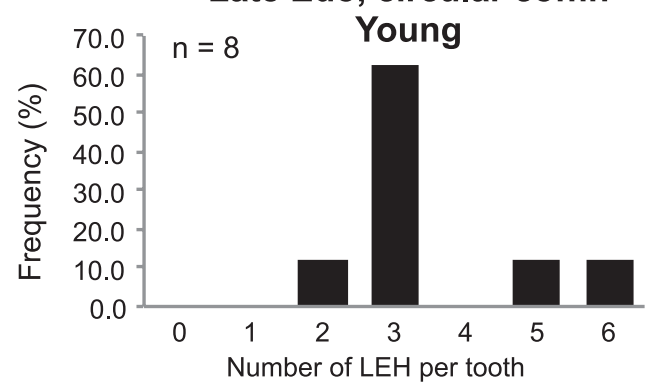

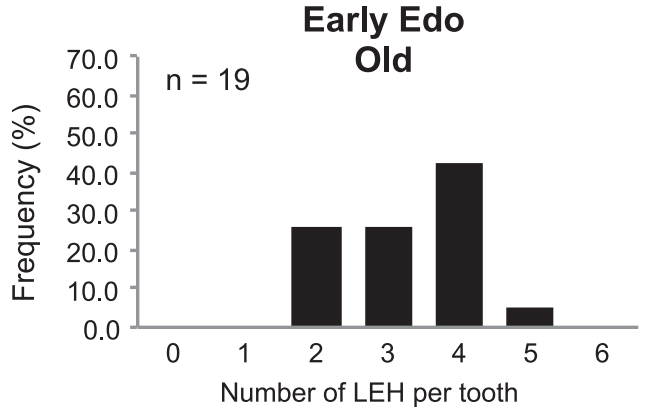

Late Edo, pooled coffin types
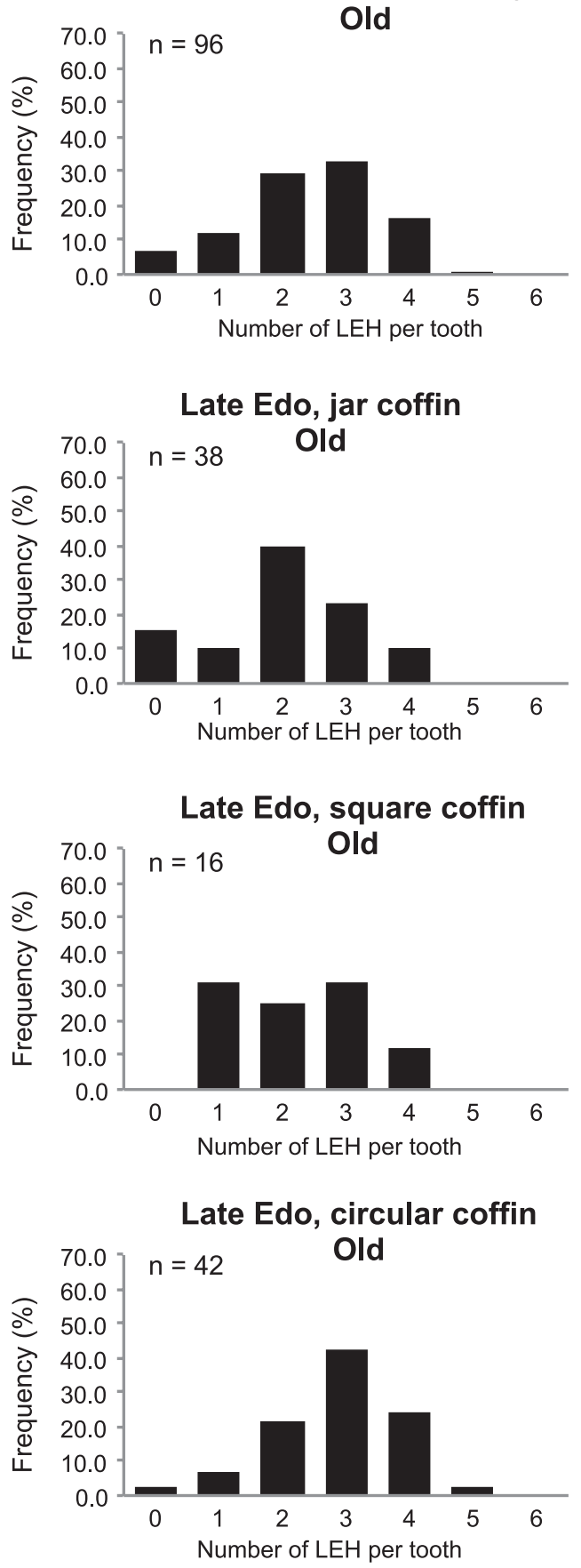

Figure 2. Frequency distribution of the number of LEHs per tooth. 
Table 4. Results of significance tests between sexes

\begin{tabular}{|c|c|c|c|}
\hline & General prevalence & Frequency distribution & Mean number of LEHs \\
\hline \multicolumn{4}{|l|}{ Early Edo period } \\
\hline Young & n.s. $(P=1.000)$ & n.s. $(P=1.000)$ & n.s. $(P=0.523)$ \\
\hline Old & n.s. $(P=1.000)$ & n.s. $(P=1.000)$ & n.s. $(P=0.831)$ \\
\hline Pooled age at death & n.s. $(P=1.000)$ & n.s. $(P=0.864)$ & n.s. $(P=0.438)$ \\
\hline \multicolumn{4}{|l|}{ Late Edo period } \\
\hline \multicolumn{4}{|l|}{ Pooled coffin types } \\
\hline Young & n.s. $(P=1.000)$ & n.s. $(P=0.636)$ & n.s. $(P=0.581)$ \\
\hline Old & n.s. $(P=0.703)$ & n.s. $(P=0.269)$ & n.s. $(P=0.205)$ \\
\hline Pooled age at death & n.s. $(P=1.000)$ & n.s. $(P=0.268)$ & n.s. $(P=0.271)$ \\
\hline \multicolumn{4}{|l|}{ Jar coffin } \\
\hline Young & n.s. $(P=1.000)$ & n.s. $(P=0.709)$ & n.s. $(P=0.641)$ \\
\hline Old & n.s. $(P=0.672)$ & n.s. $(P=0.259)$ & n.s. $(P=0.494)$ \\
\hline Pooled age at death & n.s. $(P=0.417)$ & n.s. $(P=0.598)$ & n.s. $(P=0.424)$ \\
\hline \multicolumn{4}{|l|}{ Square coffin } \\
\hline Young & N/A & N/A & N/A \\
\hline Old & n.s. $(P=1.000)$ & n.s. $(P=0.401)$ & n.s. $(P=0.818)$ \\
\hline Pooled age at death & N/A & N/A & N/A \\
\hline \multicolumn{4}{|l|}{ Circular coffin } \\
\hline Young & n.s. $(P=1.000)$ & n.s. $(P=0.643)$ & n.s. $(P=0.574)$ \\
\hline Old & n.s. $(P=0.191)$ & n.s. $(P=0.431)$ & n.s. $(P=0.062)$ \\
\hline Pooled age at death & n.s. $(P=0.200)$ & n.s. $(P=0.350)$ & n.s. $(P=0.246)$ \\
\hline
\end{tabular}

n.s., not significant.

Table 5. Results of significance tests between the young and old groups

\begin{tabular}{lccc}
\hline & General prevalence & Frequency distribution & Mean number of LEHs \\
\hline $\begin{array}{l}\text { Early Edo period } \\
\text { Late Edo period }\end{array}$ & n.s. $(P=0.345)$ & $*(P=0.022)$ & n.s. $(P=0.369)$ \\
$\quad$ Pooled coffin types & n.s. $(P=0.598)$ & $*(P=0.049)$ & $*(P=0.035)$ \\
Jar coffin & n.s. $(P=0.315)$ & n.s. $(P=0.402)$ & n.s. $(P=0.089)$ \\
Square coffin & N/A & N/A & N/A \\
Circular coffin & n.s. $(P=1.000)$ & n.s. $(P=0.139)$ & n.s. $(P=0.127)$ \\
\hline
\end{tabular}

$* P<0.05$; n.s., not significant.

Table 6. Results of significance tests between time periods

\begin{tabular}{|c|c|c|c|}
\hline & General prevalence & Frequency distribution & Mean number of LEHs \\
\hline \multicolumn{4}{|l|}{ Early vs late pooled group } \\
\hline Young & n.s. $(P=0.345)$ & $*(P=0.027)$ & n.s. $(P=0.182)$ \\
\hline Old & n.s. $(P=0.598)$ & n.s. $(P=0.066)$ & $* *(P=0.004)$ \\
\hline Pooled age at death & n.s. $(P=1.000)$ & $* *(P=0.001)$ & $* *(P=0.000)$ \\
\hline \multicolumn{4}{|c|}{ Early vs late jar coffin group } \\
\hline Young & n.s. $(P=0.476)$ & n.s. $(P=0.105)$ & n.s. $(P=0.098)$ \\
\hline Old & n.s. $(P=0.164)$ & $*(P=0.016)$ & $* *(P=0.000)$ \\
\hline Pooled age at death & n.s. $(P=0.248)$ & $* *(P=0.002)$ & $* *(P=0.000)$ \\
\hline \multicolumn{4}{|c|}{ Early vs late square coffin group } \\
\hline Young & N/A & N/A & N/A \\
\hline Old & n.s. $(P=1.000)$ & $*(P=0.034)$ & $* *(P=0.005)$ \\
\hline Pooled age at death & N/A & N/A & N/A \\
\hline \multicolumn{4}{|c|}{ Early vs late circular coffin group } \\
\hline Young & n.s. $(P=1.000)$ & $*(P=0.044)$ & n.s. $(P=0.685)$ \\
\hline Old & n.s. $(P=1.000)$ & n.s. $(P=0.3946)$ & n.s. $(P=0.147)$ \\
\hline Pooled age at death & n.s. $(P=1.000)$ & $*(P=0.0349)$ & n.s. $(P=0.084)$ \\
\hline
\end{tabular}

\footnotetext{
* $P<0.05 ; * * P<0.01 ;$ n.s., not significant.
} 
were significantly different from that of the early Edo period $(P<0.05$; Table 6$)$. No significant difference was found in the mean number of LEHs between the young groups ( $P \geq 0.05$; Table 6). Comparisons between the old groups showed that the jar coffin and the square coffin groups had both significantly different frequency distributions and significantly lower mean numbers of LEHs compared to the early Edo period group $(P<0.05$; Table 6$)$. There was also a significant difference between the old individuals of the early Edo period and those of the pooled late Edo period in the mean number of LEHs $(P<0.05$; Table 6$)$. No significant difference was found between the old individuals of the ear-

Table 7. Number of individuals in each attrition stage

\begin{tabular}{lrr}
\hline & \multicolumn{1}{c}{ Mild } & \multicolumn{1}{c}{ Severe } \\
\hline $\begin{array}{l}\text { Occlusal attrition } \\
\text { Early Edo period }\end{array}$ & & \\
$\quad$ Young & $8(80.0 \%)$ & $2(20.0 \%)$ \\
Old & $4(21.1 \%)$ & $15(78.9 \%)$ \\
Late Edo period & & \\
$\quad$ Young & $16(84.2 \%)$ & $3(15.8 \%)$ \\
$\quad$ Old & $34(35.4 \%)$ & $62(64.6 \%)$ \\
Buccal attrition & & \\
Early Edo period & & \\
$\quad$ Young & $9(90.0 \%)$ & $1(10.0 \%)$ \\
$\quad$ Old & $13(68.4 \%)$ & $6(31.6 \%)$ \\
Late Edo period & & \\
$\quad$ Young & $10(52.6 \%)$ & $9(47.4 \%)$ \\
$\quad$ Old & $46(47.9 \%)$ & $50(52.1 \%)$ \\
\hline
\end{tabular}

The numbers in parentheses indicate the percentages of individuals in each age-at-death group of each time period. ly Edo group and those of the circular coffin group in the frequency distribution or in the mean number of $\mathrm{LEH}$ $(P \geq 0.05$; Table 6).

\section{Difference between the different stages of attrition}

Table 7 shows the number of individuals in each stage of occlusal and buccal attrition, and Table 8 indicates the number of LEHs per tooth by different stages of occlusal and buccal attrition. The percentage of individuals with severe occlusal attrition was higher for the old groups than for the young groups regardless of time period. The percentage of individuals with severe buccal attrition was higher for the old groups, and for the late Edo period groups. Comparison of the frequency distribution or of the mean number of LEHs per tooth between the different stages of occlusal and buccal attrition revealed no significant difference in any time period or age-at-death group $(P \geq 0.05$; Table 9$)$.

\section{Discussion}

The aim of the present study was to investigate whether there was any diachronic change in the pattern of LEH occurrence between the early and late Edo period. The results show that the late Edo period individuals tend to have fewer LEHs than those of the early Edo period. Significant differences between the two time periods were found not only within the pooled age-at-death category but also within each age-at-death category regarding the frequency distribution and the mean number of LEHs per tooth. It was also revealed that the young individuals tended to have more LEHs than the old individuals regardless of the time period.

There are several factors other than the time period that

Table 8. Number of LEHs per tooth by different attrition stages

\begin{tabular}{|c|c|c|c|c|c|c|c|c|c|}
\hline & \multirow{2}{*}{$\begin{array}{l}\text { Attrition } \\
\text { stage }\end{array}$} & \multicolumn{7}{|c|}{ Number of LEHs per tooth } & \multirow{2}{*}{$\begin{array}{l}\text { Mean number } \\
\text { of LEHs }\end{array}$} \\
\hline & & 0 & 1 & 2 & 3 & 4 & 5 & 6 & \\
\hline \multicolumn{10}{|c|}{ Occlusal attrition } \\
\hline \multicolumn{10}{|c|}{ Early Edo period } \\
\hline \multirow[t]{2}{*}{ Young } & Mild & 1 & 0 & 1 & 1 & 1 & 4 & 0 & 3.6 \\
\hline & Severe & 0 & 0 & 0 & 0 & 1 & 1 & 0 & 4.5 \\
\hline \multirow[t]{2}{*}{ Old } & Mild & 0 & 0 & 0 & 2 & 2 & 0 & 0 & 3.5 \\
\hline & Severe & 0 & 0 & 5 & 3 & 6 & 1 & 0 & 3.2 \\
\hline \multicolumn{10}{|c|}{ Late Edo period } \\
\hline \multirow[t]{2}{*}{ Young } & Mild & 0 & 1 & 4 & 7 & 1 & 2 & 1 & 3.1 \\
\hline & Severe & 0 & 0 & 1 & 2 & 0 & 0 & 0 & 2.7 \\
\hline \multirow[t]{2}{*}{ Old } & Mild & 3 & 4 & 12 & 9 & 6 & 0 & 0 & 2.3 \\
\hline & Severe & 4 & 8 & 16 & 23 & 10 & 1 & 0 & 2.5 \\
\hline \multicolumn{10}{|c|}{ Buccal attrition } \\
\hline \multicolumn{10}{|c|}{ Early Edo period } \\
\hline \multirow[t]{2}{*}{ Young } & Mild & 1 & 0 & 1 & 1 & 1 & 5 & 0 & 3.8 \\
\hline & Severe & 0 & 0 & 0 & 0 & 1 & 0 & 0 & 4.0 \\
\hline \multirow[t]{2}{*}{ Old } & Mild & 0 & 0 & 3 & 3 & 6 & 1 & 0 & 3.4 \\
\hline & Severe & 0 & 0 & 2 & 2 & 2 & 0 & 0 & 3.0 \\
\hline \multicolumn{10}{|c|}{ Late Edo period } \\
\hline \multirow[t]{2}{*}{ Young } & Mild & 0 & 0 & 1 & 6 & 1 & 2 & 0 & 3.4 \\
\hline & Severe & 0 & 1 & 4 & 3 & 0 & 0 & 1 & 2.7 \\
\hline \multirow[t]{2}{*}{ Old } & Mild & 1 & 6 & 16 & 17 & 6 & 0 & 0 & 2.5 \\
\hline & Severe & 6 & 6 & 12 & 15 & 10 & 1 & 0 & 2.4 \\
\hline
\end{tabular}


Table 9. Results of significance tests between different attrition stages

\begin{tabular}{lccccc}
\hline & \multicolumn{2}{c}{ Occlusal attrition } & & \multicolumn{2}{c}{ Buccal attrition } \\
\cline { 2 - 2 } \cline { 5 - 6 } & Frequency distribution & Mean & & Frequency distribution & Mean \\
\hline Early Edo period & & & & N/A & N/A \\
$\quad$ Young & n.s. $(P=1.000)$ & n.s. $(P=0.544)$ & & n.s. $(P=0.419)$ \\
Old & n.s. $(P=0.613)$ & n.s. $(P=0.583)$ & & n.s. $(P=1)$ & n.s. $(P=0.200)$ \\
Late Edo period & n.s. $(P=1.000)$ & n.s. $(P=0.567)$ & & n.s. $(P=0.126)$ & n.s. $(P=0.810)$ \\
$\quad$ Young & n.s. $(P=0.857)$ & n.s. $(P=0.520)$ & & n.s. $(P=0.289)$ & \\
Old & & & & &
\end{tabular}

n.s., not significant.

could have affected the LEH occurrence patterns observed in this study, including the age-at-death and sex distribution, attrition, social status, and geographical location. To examine whether the observed difference between time periods is attributable to diachronic change, it is necessary to discuss the extent to which these factors affected the observed patterns of LEH occurrence.

As mentioned before, LEH occurrence has been shown to be associated with the age-at-death of an individual in several populations (Šlaus, 2000; Palubeckaitè et al., 2002; Koga, 2003). In this study, the early Edo period group included a larger proportion of young individuals, and the young individuals tended to have more LEHs than the old individuals regardless of time period. However, as the LEH occurrences were compared between the groups of same age-at-death category, the effect of difference in the age-at-death distribution on the results can be considered as controlled.

Sex distribution is another factor that can affect the pattern of LEH occurrence in a population. Oyamada et al. (2012) demonstrated that Edo period females had higher prevalence of LEH than males in Fukuoka, western Japan. Among the 18th- and 19th-century population in Edo, however, no significant difference in LEH prevalence or number of LEHs per individual was found between sexes in any coffin groups (Nakayama, 2016). In this study, no significant difference in the LEH occurrence patterns was found between sexes in any time period or coffin group, and it is unlikely that the variation of sex distribution among different groups had an effect on the comparison of LEH occurrences. As suggested by Nakayama (2016), the inconsistency of results among the Edo period populations may be caused by regional differences. That is, the inequality in the physical and cultural environment between male and female children in Fukuoka may have been larger than that in Edo.

As for the attrition, the late Edo period groups tended to show larger proportions of individuals with severe buccal attrition. However, there was no significant difference in the frequency distribution or in the mean number of LEHs per tooth between the different stages of buccal attrition. Therefore, the effect of buccal attrition on the comparison can be regarded as minimal.

Social status was also considered when comparing groups of the different time periods. Nakayama (2016) suggested that the LEH occurrence is associated with social status; individuals in the circular coffin group showed higher prevalence and a larger number of LEHs compared with those in the jar coffin group in 18th- to 19th-century Edo (Nakayama,
2016). In this study, not only the jar coffin group but also the circular coffin group of the late Edo period had fewer LEHs than the early Edo period group. Therefore, although the social status of the early Edo period individuals cannot be estimated as mentioned above, the observed differences between the time periods can be regarded as systematic differences.

Because the individuals examined in this study were all excavated from graveyards within the area of Edo, the effect of geographical differences on the results is seemingly controlled. However, it does not necessarily mean that the observed individuals all grew up in the city of Edo. The city of Edo attracted a large population from outside the city throughout the Edo period (Sekiyama, 1958). At present, whether there was any difference in LEH occurrence between the population within the city of Edo and that outside of Edo has not been fully investigated, and one cannot rule out the possibility that the proportion of immigrants from outside the city of Edo changed throughout this time, causing the difference in LEH occurrence between the time periods.

To summarize, most of these factors had a controlled or relatively small effect on the comparison of LEH occurrence patterns in this study, although one cannot exclude the possibility that geographical difference or migration could have affected the result. If the effect of geographical difference or migration was minimal, it seems probable that the observed difference in LEH occurrence can be attributed to its diachronic change.

The formation of LEH is associated with various systemic stresses (May et al., 1993; Zhou and Corruccini, 1998; Seow, 2014). If there was a straightforward relationship between the observed LEH frequency and the overall health status of the Edo period population, it can be assumed that the late Edo period individuals were exposed to less systemic stresses compared with the early Edo period individuals as a result of improvements in overall childhood health status during the 17th century. Alternatively, there may have been a paradoxical relationship known as the 'osteological paradox.' The concept of 'osteological paradox' was originally proposed by Wood et al. (1992). They identified the issues of demographic non-stationarity, selective mortality, and hidden heterogeneity of frailty as conceptual challenges in paleopathology, and argued that a paradoxical interpretation can equally be possible under some circumstances (Wood et al., 1992). That is, the absence of skeletal lesion may indicate that the individual experienced quite severe physiologi- 
cal insults and died before the development of skeletal lesions, and a population with low frequencies of skeletal lesions can be interpreted as a relatively unhealthy population (Wood et al., 1992). Throughout their article, they emphasized the necessity of careful consideration of the interpretation of skeletal lesions and the health status of past populations (Wood et al., 1992). In the case of this study, it can be assumed that the late Edo period individuals were exposed to severe systemic stresses and died before the formation of multiple LEHs, which resulted in lower frequency and fewer LEHs compared with the early Edo period individuals.

One way to address the issue of the osteological paradox is to compare lesion frequencies among age-at-death categories (Wright and Yoder, 2003; DeWitte and Stojanowski, 2015). In this study, the young individuals, who can be regarded as relatively frail individuals, tended to have more LEHs than the old individuals. The tendency of the younger individuals to have more LEHs than the older individuals has also been reported in previous studies (Šlaus, 2000; Palubeckaitè et al., 2002; Koga, 2003). Further, Boldsen (2007) demonstrated that male individuals with LEHs experienced higher death rates than those without LEHs in a medieval Danish population. The results in this study and the findings from these previous studies indicate that the formation of LEH is associated with relative frailty, rather than robustness. Therefore, a paradoxical interpretation seems less likely, and a straightforward interpretation is more appropriate, in which the late Edo period individuals were assumed to have been exposed to less systemic stresses than the early Edo period individuals.

Historical evidence also supports this straightforward interpretation. In general, 17th-century Japan witnessed great social changes. In 1603, the Tokugawa Shogunate took control and kept the country under a feudal system, which lead to the beginning of the Edo period. In the early 17th century, the expansion of commodity distribution driven by the Tokugawa regime contributed to the development of large cities, including Edo, which attracted a large number of merchants and craftspeople (Tamai, 1992). At the same time, peasants in the countryside became more independent of their lords and began to form smaller families. All these movements resulted in improvements in general living conditions and a population increase from the beginning of the 17 th century until the early 18 th century, followed by population stagnation from the mid-18th century (Kito, 2001). Historical demographic studies also suggest the increase in life expectancy of farmers as well as warriors during the 17 th century (Kito, 2001).

The children's environment also seems to have changed around this time. Infant mortality is thought to have decreased during the 17 th century due to improvements in general living conditions (Kito, 2001). From around the early 18th century, local authorities began to implement various policies to protect abandoned babies, support parents economically, and support breastfeeding (Sawayama, 2017). In addition, developments in printing promoted the spread of knowledge on child rearing (Yamazumi and Nakae, 1976).

The city of Edo itself also experienced various social changes during the 17 th century. Large-scale development of the capital began in the early 17 th century with the expansion of Edo castle and the reclamation of inlets, followed by the construction of the outer moat of the castle (Naito, 1966). Residential areas for feudal lords and their retainers, as well as commercial zones for townspeople, were constructed in the early 17 th century. Principal waterworks were installed by the mid-17th century (Naito, 1966), which marks the establishment of the basic infrastructure of the city of Edo.

Public safety in the city of Edo also improved by the beginning of the 18th century. The expanding city of Edo in the 17 th century was not necessarily safe and peaceful. Much of the construction work was carried out by former common soldiers from the Warring States period who were hired by feudal lords or their retainers (Fujiki, 1995). These workers are thought to have lived in poor conditions and were exposed to life-threatening risks because of heavy physical labor, street murders, or execution by their masters (Fujiki, 1995; Tsukamoto, 2001). Public safety within the city of Edo was not assured until the beginning of the 18th century (Tsukamoto, 2001).

The historical background mentioned above suggests that the entire living conditions in the city of Edo, including the children's environment, were improving during the 17 th century and stabilized in the 18th century. These social changes are compatible with the assumption that childhood health status improved in the 17 th century, which caused the differences in LEH occurrence between the time periods.

The findings of this study indicate that diachronic changes in hypoplasia occurrence can be observed even in populations that have experienced no major transition in subsistence or any full-scale contact with foreign populations. This study also offered a new insight into the diachronic change in hypoplasia occurrence among the Japanese population. Hypoplasia occurrence and overall childhood health status changed over a relatively short time period, as well as over a long period from prehistoric to modern period as shown by Yamamoto (1988) and Koga (2003). In terms of the variation within the Edo period population, it was shown that hypoplasia occurrence varied not only between sexes (Oyamada et al., 2012) or between social statuses (Nakayama, 2016), but also between time periods.

\section{Conclusions}

To investigate diachronic changes in the occurrence of LEH during the Edo period, adult skeletal remains recovered from seven burial sites in Tokyo were examined for LEH prevalence and the number of LEHs per tooth. These individuals were divided into groups from the early Edo period (i.e., 17th century) and from the late Edo period (i.e., 18th and 19th centuries) based on written records of the graveyards and archaeological evidence. The late Edo period individuals were further divided into three coffin-type groups that correspond to different social statuses.

The results of this study show that the all three coffin-type groups of the late Edo period tended to have fewer LEHs than the early Edo period individuals, which can be regarded as systematic differences between the two time periods. This result suggests that there was a diachronic change in LEH occurrence as a consequence of the improvement in child- 
hood health status during the 17 th century, which is consistent with the historical background. The findings of this study indicate that diachronic changes in LEH occurrence can be observed even in a society with no major change in subsistence or any large-scale contact with foreign populations. Future investigation on diachronic changes in other bioarchaeological indicators of childhood health status, combined with the results of this study, will contribute to a deeper understanding of children's environment in a changing society.

\section{Acknowledgments}

The author is grateful to the Department of Anthropology, National Museum of Nature and Science, Tsukuba, for allowing access to the sample. The author also thanks Dr. Tomohito Nagaoka of the Department of Anatomy, St. Marianna University School of Medicine, and Professor Akio Tanigawa of Waseda University for their support. This work was in part supported by a Grant-in-aid for JSPS Research Fellow Grant Number 15J05577. There are no conflicts of interest to declare.

\section{References}

Aine L., Backström M.C., Mäki R., Kuusela A.L., Koivisto A.M., et al. (2000) Enamel defects in primary and permanent teeth of children born prematurely. Journal of Oral Pathology and Medicine, 29: 403-409.

Asao N. (1992) Kinsei no mibun to sono henyou. In: Asao N. (ed.), Mibun to Kakushiki. Chuokoron-sha, Tokyo, pp. 7-40 (in Japanese).

Boldsen J.L. (2007) Early childhood stress and adult age mortality: a study of dental enamel hypoplasia in the medieval Danish village of Tirup. American Journal of Physical Anthropology, 132: 59-66.

Bruzek J. (2002) A method for visual determination of sex, using the human hip bone. American Journal of Physical Anthropology, 117: 157-168.

Cucina A. (2002) Brief communication: diachronic investigation of linear enamel hypoplasia in prehistoric skeletal samples from Trentino, Italy. American Journal of Physical Anthropology, 119: 283-287.

DeWitte S.N. and Stojanowski C.M. (2015) The osteological paradox 20 years later: past perspectives, future directions. Journal of Archaeological Research, 23: 397-450.

Fujiki H. (1995) Zouhyoutachi no Senjou. Asahi Shimbun Company, Tokyo (in Japanese).

Goodman A.H. and Rose J.C. (1990) Assessment of systemic physiological perturbations from dental enamel hypoplasias and associated histological structures. Yearbook of Physical Anthropology, 33: 59-110.

Griffin R.C. and Donlon D. (2007) Dental enamel hypoplasias and health changes in the Middle Bronze Age-Early Iron Age transition at Pella in Jordan. HOMO, 58: 211-220.

Hatchobori Sanchome Iseki Dainiji Chousakai (2003) Hatchobori Sanchome Iseki Dainiji. Hatchobori Sanchome Iseki Dainiji Chousakai, Tokyo (in Japanese).

Hillson S. (1996) Dental Anthropology. Cambridge University Press, Cambridge.

Hillson S. and Bond S. (1997) Relationship of enamel hypoplasia to the pattern of tooth crown growth: a discussion. American Journal of Physical Anthropology, 104: 89-103.

Jishoin Iseki Chosadan (1987) Jishoin Iseki. Tokyo-to Shinjuk-uku Kyoiku Iinkai, Tokyo (in Japanese).

King T., Hillson S., and Humphrey L.T. (2002) A detailed study of enamel hypoplasia in a post-medieval adolescent of known age and sex. Archives of Oral Biology, 47: 29-39.

King T., Humphrey L.T., and Hillson S. (2005). Linear enamel hypoplasias as indicators of systemic physiological stress: evidence from two known age-at-death and sex populations from postmedieval London. American Journal of Physical Anthropology, 128: 547-559.

Kito H. (2001) Jinkoushi niokeru kinsei. In: Hayami Y., Kito H., and Tomobe K. (eds.), Rekishi Jinkougaku no Furontia. Toyo Keizai Inc., Tokyo, pp. 45-65 (in Japanese).

Koga H. (2003) Stress-markers in the ancient people of western Japan, 2. Cribra orbitalia, Enamel hypoplasia and the relationship between three stress markers containing Harris' line. Anthropological Science (Japanese Series), 111: 51-67 (in Japanese with English summary).

Lanphear K.M. (1990) Frequency and distribution of enamel hypoplasias in a historic skeletal sample. American Journal of Physical Anthropology, 81: 35-43.

Littleton J. (2005) Invisible impacts but long-term consequences: hypoplasia and contact in central Australia. American Journal of Physical Anthropology, 126: 295-304.

Lovejoy C.O., Meindl R.S., Pryzbeck T.R., and Mensforth R.P (1985) Chronological metamorphosis of the auricular surface of the illium: a new method for the determination of adult skeletal age at death. American Journal of Physical Anthropology, 68: 15-28.

Matsumoto K. (1990) Edo no bosei: maiso shisetsu ni mirareru buke shakai. In: Tokyo Metropolitan Board of Education (ed.), Bunkazai no Hogo, Volume 22. pp. 53-168 (in Japanese).

May R.L., Goodman A.H., and Meindl R.S. (1993) Response of bone and enamel formation to nutritional supplementation and morbidity among malnourished Guatemalan children. American Journal of Physical Anthropology, 92: 37-51.

Molnar S. (1971) Human tooth wear, tooth function and cultural variability. American Journal of Physical Anthropology, 34: $175-189$.

Naito A. (1966) Edo to Edojo. Kajima Kenkyujo Shuppan-kai, Tokyo (in Japanese).

Nakayama N. (2016) The relationship between linear enamel hypoplasia and social status in 18th to 19th century Edo, Japan. International Journal of Osteoarchaeology, 26: 1034-1044.

Oyamada J., Kitagawa Y., Manabe Y., and Rokutanda A. (2004) Dental pathology in the samurai and commoners of early modern Japan. Anthropological Science, 112: 235-246.

Oyamada J., Kitagawa Y., Kato K., Matsushita T., Tsurumoto T., and Manabe Y. (2012) Sex differences in linear enamel hypoplasia (LEH) in early modern Japan. Anthropological Science, 120: 97-101.

Palubeckaite Ž., Jankauskas R., and Boldsen J. (2002) Enamel hypoplasia in Danish and Lithuanian late medieval/early modern samples: a possible reflection of child morbidity and mortality patterns. International Journal of Osteoarchaeology, 12: 189201.

R Core Team (2014) R: A Language and Environment for Statistical Computing. R Foundation for Statistical Computing, Vienna.

Santos R.V. and Coimbra C.E., Jr (1999) Hardships of contact: enamel hypoplasias in Tupí-Mondé Amerindians from the Brazilian Amazonia. American Journal of Physical Anthropology, 109: 111-127.

Sawayama M. (2017) Edo no Chichi to Kodomo. Yoshikawa Kobunkan, Tokyo (in Japanese).

Sekiyama N. (1958) Kinsei Nihon no Jinkou Kouzou. Yoshikawa Kobunkan, Tokyo (in Japanese).

Seow W.K. (2014) Developmental defects of enamel and dentine: challenges for basic science research and clinical management. Australian Dental Journal, 59: 143-154.

Shinjukuku Hosshojiato Iseki Chosakai (1991) Hosshoji Ato. Shinjuku-ku Hosshojiato Iseki Chosakai, Tokyo (in Japanese).

Shinjukuku Koseibu Iseki Chosakai (1993) En'oji Ato. Shinjukuku Koseibu Iseki Chosakai, Tokyo (in Japanese). 
Šlaus M. (2000) Biocultural analysis of sex differences in mortality profiles and stress levels in the late medieval population from Nova Rača, Croatia. American Journal of Physical Anthropology, 111: 193-209.

Taisei Enjiniaringu Kabushiki Gaisha (2005) Sugenji Shokenji Ato. Meiji Jingu, Tokyo (in Japanese).

Tamai T. (1992) Kinsei toshikukan no tokushitsu. In: Yoshida N. (ed.), Toshi no Jidai. Chuokoron-sha, Tokyo, pp. 33-80 (in Japanese).

Tanigawa A. (1992) Excavating Edo's cemeteries: graves as indicators of status and class. Japanese Journal of Religious Studies, 19: 271-297.

Tanigawa A. (1993) En'oji ato niokeru maisoushisetsu to hukusouhin. In: Shinjuku-ku Koseibu Iseki Chosakai (ed.), En'oji Ato. Shinjuku-ku Koseibu Iseki Chosakai, Tokyo, pp. 106-110 (in Japanese).

Tanigawa A. (2004) Edo no haka no maisoushisetsu to hukusouhin. In: Edoiseki Kenkyukai (ed.), Haka to Maisou to Edojidai. Yoshikawa Kobunkan, Tokyo, pp. 224-250 (in Japanese).

Tokyoto Chuoku Kyouiku Iinkai (1988) Hatchobori Sanchome Iseki. Tokyoto Chuo-ku Kyouiku Iinkai, Tokyo (in Japanese).

Tokyoto Chuoku Kyouiku Iinkai (1989) Hatchobori Nichome Ise- ki. Tokyoto Chuo-ku Kyouiku Iinkai, Tokyo (in Japanese). Toritsugakko Iseki Chosakai (1990) Toeizan Kan'eiji Gokokuin I, II. Toritsugakko Iseki Chosakai, Tokyo (in Japanese).

Tsukamoto M. (2001) Ikiru Koto no Kinseishi: Jinmei Kankyo no Rekishi Kara. Heibonsha, Tokyo (in Japanese).

Wood J.W., Milner G.R., Harpending H.C., and Weiss K.M. (1992) The osteological paradox: problems of inferring prehistoric health from skeletal samples. Current Anthropology, 33: 343-370.

Wright L.E. and Yoder C.J. (2003) Recent progress in bioarchaeology: approaches to the osteological paradox. Journal of Archaeological Research, 11: 43-70.

Yamamoto M. (1988) Enamel hypoplasia of the permanent teeth in Japanese from the Jomon to the Modern periods. Journal of the Anthropological Society of Nippon, 96: 417-433 (in Japanese with English summary).

Yamazumi M. and Nakae K. (eds.) (1976) Kosodate no Sho. Heibon-sha, Tokyo (in Japanese).

Zhou L. and Corruccini R.S. (1998) Enamel hypoplasias related to famine stress in living Chinese. American Journal of Human Biology, 10: 723-733. 